\title{
Comparative Research into Conflict in Tamil Nadu
}

\section{Introduction}

In India 2020. A vision for the new millennium Dr A.P.J. Abdul Kalam, eleventh president of India (2002-2007) and hailing from Tamil Nadu, recalls the lasting impression left on him by Mahatma Gandhi's resolve to be with those affected by religio-political conflict on the historic day of Indian independence: "I was in my teens when India became independent. The headmaster of my school used to take us to hear the news on the only available radio. We used to hear of the events in Delhi, and many speeches and commentaries. I used to distribute the morning newspaper Dinamani to households in Rameswaram, to help my brother with his work. While going on my daily morning round I also read the news items. One report which particularly struck me appeared in the heady days following independence. It was a time of celebration and the country's leaders were gathered in Delhi, addressing themselves to the momentous tasks that faced the government. At this moment, however, far from being at the centre of power, the father of the nation, Mahatma Gandhi, was away in Noakhali caring for the riot victims and trying to heal the wounds inflicted by communal rioting. How many persons would have such courage of conviction as did Gandhiji at a time when the nation was at his command?" (Abdul Kalam \& Rajan 1998, 3-4).

This narrative in a way captures the overall rationale and context of our research: it shows how religions can motivate people to get caught up in the tragedy of violence or become an embodiment of compassion amidst violence and death. In another childhood memory in his recent book, My journey. Transforming dreams into actions, Dr Abdul Kalam also recalls how his father Jainulabdeen, the imam of Rameswarm mosque, would meet with his two close friends, Pakshi Lakshmana Sastry, the priest of the Ramanathaswamy temple, and father Bodal, priest of the lone church in the town. "The memory of these three learned men is still etched in my mind. I can still see them - one in his turban and imam's cloak, another in his dhoti and the third in his cassock. They met every Friday evening at around four-thirty and discussed matters of religion and the happenings of the town. Sometimes people came to visit them at that time with specific issues to be resolved, or the three men kept each other apprised of anything that could potentially threaten the peace among the people and together, they tried to work out ways of clearing [up] miscom-

(C) ANTHONY, HERMANS \& STERKENS, 2015 | DOI 10.1163/9789004270862_003

This is an open access chapter distributed under the terms of the Creative Commons AttributionNoncommercial 3.o Unported (CC-BY-NC 3.e) License. 
munication or scotching rumours before they assumed dangerous proportions. The fundamental requirement for peace - effective communication among sections of the people - was always kept alive by these three patriarchs" (Abdul Kalam 2013, 33-34).

These narratives about the meeting of religions and the dual role they may play with regard violence and peace in a complex and pluralistic society like India stand out against the backdrop of religious socialization in the family and educational environment. Exploring the potential of religions in the lived experience of students is in fact the basic thrust of our research.

\subsection{Focus and Scope of the Research}

The violence unleashed between Hindus and Muslims at the time of the partition between India and Pakistan was one of the darkest events in the history of a people who gained their independence through satyagraha ${ }^{1}$ (non-violent resistance relying on the strength of truth). Not that there have been no religious conflicts in the long history of the subcontinent. Although political conflicts between Hindus, Buddhists, Jains, Muslims and Christians have marred Indian history time and again, there has been constant and conscious observance of religious tolerance at least since the time of Ashoka, the Buddhist emperor of the 3 rd century всE.

In the contemporary global scenario there are those who warn us that the 21st century could be gravely tarnished by a 'clash of civilizations', in which people's cultural and religious identities will be the primary source of conflict (Huntington 1996). Frequent outbursts of religiously motivated violence suggest that the predictions may not be totally false. Even so, conflict among followers of different religions is nothing unusual; it has in fact blemished the history of peoples all over the world. What is new is that in a globalized world religious tensions localized in one part of the globe can assume unforeseen proportions. If there are prophets who warn us of conflicts to come, there are others who desperately seek to contain violence and care for its victims. With religious violence sporadically flaring up, specialized centres for conflict management and conflict resolution have also sprung up in various parts of the world. Research to uncover the underlying causes of religious violence and

1 For transliteration of Sanskrit and Tamil words, we have followed the contemporary trend of keeping the diacritical marks to the minimum. On the basis of the proposal by Jacobsen (2009) in Brill's encyclopedia of Hinduism, for Tamil transliteration a common scheme has been used with the palatal s usually rendered as c, and the alveolars as $\underline{n}, \underline{r}, \underline{l}$. 
efforts to contain it have their significance, but our research distinguishes itself from such projects for two reasons.

In the first place, our study seeks to identify the factors - present in ordinary day-to-day life - that contribute to the attribution of religious conflict to forcedriven causes. ${ }^{2}$ In other words, we seek to analyse the attribution of religious conflict, and not conflict or violence as such. Are there elements in the normal life of persons which explain their attribution of conflict to specific causes? Identifying these could have some strategic relevance for the education of the young.

That brings us to the other characteristic aspect of our research. Our study of religion and conflict was conducted in an educational context. That is to say, we seek to identify those elements in the life and experience of young college students that can predictably incline them to religious violence. We hope that the findings of the present research will help to evolve educational strategies that can serve as a preventive measure. Knowing the tragic consequences of religious violence, there is no gainsaying that prevention is better than cure. If education is not preventive, perhaps it lacks some essential quality (International Congress on Preventive System and Human Rights 2009).

With this general focus and scope in mind we situate our research in the multireligious context of Tamil Nadu, India. Although there have been sporadic moments of religious conflict in the past and recently during the last two decades of the 2oth century, Tamil Nadu - as we shall explain below - by and large is a place where Hinduism, Christianity and Islam have coexisted peacefully, enriching the local culture and society.

\subsection{Religious and Cultural Context of the Research}

Geographical or national boundaries are one way of identifying a culture. Thus in reference to India one speaks of Indian culture. Though it is a useful category, 'Indian culture' is actually a mosaic of cultures, a composite culture with an underlying unity. In such a context it seems more appropriate to define culture in terms of language, for language "is the reservoir of tradition and the medium in and through which we exist and perceive the world" (Gadamer 2008, 29). It

2 The concept of force-driven religious conflict will be explained in more detail in chapter 7 . It implies coercive power as a means to achieve the economic, political or socio-cultural goals of religious groups. Force-driven religious conflict does not refer to the personal willingness of individuals to engage in religious conflicts. Neither does it measure the extent to which violent behaviour is acceptable to the respondent. It indicates the extent to which the respondent attributes interreligious conflicts to force-driven causes. 
is through language that we grasp the time-tested experiences of people in grappling with reality. In this sense, and by virtue of being situated outside the sphere of northern Indian empires yet on the maritime trade routes to Europe and West Asia, Tamil Nadu represents a cultural unit with a history of its own (More 2004). Our option for the Tamil cultural context was motivated particularly by the longstanding presence of Christianity and Islam in a culture closely bound to Hinduism, Buddhism and Jainism. However, we cannot disregard the wider panorama of Indian history and the struggle to define Indian identity and heritage, in which religions and cultures have played and continue to play a role. In the 2001 census, out of 1.028 million people, a little over 827 million $(80,5 \%)$ identified themselves as followers of the Hindu religion, 138 million $(13,4 \%)$ as Muslims or followers of Islam, 24 million $(2,3 \%)$ as Christians, 19 million $(1,9 \%)$ as Sikh, 8 million $(0,8 \%)$ as Buddhists and 4 million $(0,4 \%)$ as Jain. In addition over 6 million reported adherence to religions and faiths - including tribal religions - other than the six main religions. In the southern state of Tamil Nadu the proportion alters to $88,1 \%$ Hindus, 6,1\% Christians and $5,6 \%$ Muslims in a total population of 62.405 .679 in 2001. ${ }^{3}$ This is the background to our cross-religious comparative study in Tamil Nadu.

\subsubsection{Tamil Culture and Hindu Religion}

Tamil Nadu is the home of one of the most ancient cultures on the subcontinent, and Tamil is the longest surviving, living literary language of India. Without entering into a debate whether Dravidians or Tamils are indigenous to India or are of Mediterranean, African or Far Eastern origin, we may safely affirm that their culture is pre-Aryan and has played a key role in shaping Indian culture together with its Aryan counterpart (Oppert 1988; Slater 1987; Thani Nayagam 1970). According to Panneerselvam (2010, 1), "The name, 'Dravidian', a modification of 'Tiru(v)idam', a land of shrines, was applied to Tamilaham by immigrants for some geographical reason or other. There is a theory that the Indus people were Dravidians, because the Sumerians with whom they had such intimate relations are believed to belong to the same ethnic group as the Dravidians."

3 The latest national census was held in 2011 (reference date 1 March). The provisional figures of 2011 reflect a total population of India of 1.210 .193 .422 people, $72.138 .95^{8}$ people living in Tamil Nadu. The final population statistics (including figures on religion) of the 2011 census are likely to be released by the Directorate of Census Operation of the Ministry of Home Affairs later. But while other data have become available relatively fast, data on religion are not released yet as of October 2014. This gives rise to speculations about the reasons why the census 2011 remains silent on religious data. One among them, is the politically unwelcome fact that the proportion of Hindus would have declined in favour of the number of Muslims and people who consider themselves as non-religious. See http://censusindia.gov.in. 
In India, as in other parts of the world, regional identities formed around agricultural core areas. These fertile cores to which people gravitated became centres of the growth of distinctive linguistic and political regions. In South India around the Cauvery river delta Tamilaham or Tamil Nadu developed as a distinct cultural entity over the last two thousand years. Exterior historical evidence dating back to the 4 th century BCE refers to three major kingdoms of the Tamils - the Cêras (on the west coast), the Chölas (with the Cauvery delta as their base) and the Pāndiyas (with Madurai as their centre) - and to their trade with western Asia, Egypt, and later with the Greek and Roman empires (Ryerson 1988; Thapar 2003).

Tamil is one of the four literary Dravidian languages which comes closest to the parent proto-Dravidian language. It has the richest and most ancient literature, paralleled in India only by that of Sanskrit (Zvelebil 1992). Tholkāppiyam (circa 3rd century вСЕ) and Cankam literature (from 2nd century вСЕ to 3rd century CE) are the earliest extant works in Tamil and undeniably represent the golden age of Tamil literature (Subrahmanian 1981; Swaminathan 1992; Varadarajan 1972). Among these early Tamil works Thirukkural, composed by Thiruvalluvar (some time in the first three centuries CE), excels as a monumental work of lofty wisdom and a compendium of Tamil cultural values. It expounds the three basic purposes or meanings of life as understood in Tamil culture: aram (virtue, righteousness), porul (wealth) and inbam (happiness) (Panneerselvam 2010; Thapar 2003). The Bhakti movement of the Śaivite (Nāyanmārs) and Vaiṣnavite (Ālvārs) singers from the 6th to the 1oth century marks another major period in Tamil Nadu's literary and religious history (Ryerson 1988; Subrahmanian 1981; Neill 1974).

In the religious core of Tamil culture Śaivism occupies a prominent place. The history of the Tamils is almost identical with the history of Śaivism. ŚaivaSiddhāntham (originating in the 13th century) represents an apex of the philosophico-theological tradition in India (Rajasingham 1986; Dayanandan 1988; Jaswant Raj 1989). One of the finest features of ancient Tamil society was its religious tolerance and spirit of free enquiry. "Yām perra inbam peruga iv vaiyakam" (May the entire world share in the happiness that has been granted to us) aptly describes the universalistic outlook of Tamil culture (Hirudayam 1977).

Language, culture and religion have grown in an interrelated way in Tamil to give birth to what may be termed the Tamil-Śaiva culture. In it Siva is worshiped as Natarāja (the great dancer) and Tamil is cultivated in its threefold structure: iyal (literature), isai (music) and nādakam (drama/dance). Carnātic music and bharata dance have a longstanding tradition in Tamil country (Rajasingham 1986; Perumal 1982). Temple art and architecture in their turn show 
that Tamil culture has grown in harmony with the universe, nature and the body. It has flourished through the centuries in close association with the land, seasons and gods, with two core values: love and happiness (Rajasingham 1986; Arulsamy 1990). Age-old domestic and social customs testify to these. However, like other cultures, ancient Tamil culture is not without less laudable elements (Dubois 1897; Biardeau 1989).

Over the centuries Dravidian/Tamil culture and Aryan/Sanskrit culture underwent a process of mutual assimilation. In spite of the dominance of Aryans in certain areas of life as a result of the caste system, the old Tamil values and practices survived through country schools, which passed on the wisdom of the Cankam age, the hymns of the Tèvāram, the ethos of the Thirukkural, the local history and folklore. The pre-Vedic traditions, Âgamic forms of worship and popular religiosity relating to Murukan, the forest god of hills and mountains (Gandhidasan 1988; Clothey 2009; Venkatesan 2009), and the Ammans (mother goddesses) persisted in the face of the advance of Sanskrit religion (Hirudayam 1977; Grafe 1990). In the 2oth century this undaunted persistence blossomed into a Tamil renaissance: the discovery of a Tamil culture distinct from Indian culture in general. The Tamil renaissance was spearheaded by the Dravidian Association or Tamil Cañkam (1916), E.V. Ramasamy's Drāvida Kalakam (1944) and later by the Drāvida Munnêrra Kalakam (1949) of C.N. Annadurai (Grafe 1990; Ryerson 1988).

This brings us to the period of defining Indian identity and heritage in the struggle for Indian independence and in the current situation (to be discussed below).

\subsubsection{Christianity in the Tamil Cultural Context}

The volume of traffic between Socotra and Muziris (near present-day Cochin in Kerala) generated by Indo-Roman trade that brought Egyptian Jews and Greeks from Alexandria and the eastern Mediterranean, must have given rise to the tradition of St Thomas coming to Malabar in about $52 \mathrm{CE}$. A Syriac manuscript from 1770 reports that Thomas first went to Mylapore in the southern part of Tamil Nadu's capital city Chennai. He then moved to the hill country of Cherakon, where he is said to have established seven churches before itinerating in Malabar for thirty years. Tradition has it that on his return to Pāndiyan (Tamil) country to preach the gospel he was killed by a Brahmin and buried in Mylapore (Neill 1984). The available literary and archaeological evidence does not shed much light on the tradition that the church in South India was founded by the apostle Thomas. Instead, "historical links that date to the mid-first millennium AD seem stronger with Edessa and the Persian Church. A group of Christians led by Thomas Cana migrated to Kerala, where they were given a 
grant of land by the local king. The first coming of Christianity to India is more likely linked to the establishing of the Syrian Christian Church" (Thapar 2003, 279).

At all events, there is evidence of well-established churches in parts of South India no later than the beginning of the 6th century. It is also probable that these churches were at least partly made up by foreigners, and that "a part at least of the indigenous element in the Indian Church belonged originally not to Kerala but to the Pāndiyan kingdom. The continuance over many centuries of the tradition associating St Thomas with Mylapore suggests that the first Christianization of that area goes back to very early times" (Neill 1984, 33f).

However, on the arrival of the colonizers and missionaries in the early 16 th century there was almost no trace of a Christian presence in Tamil Nadu. It appears that the Christians from the Coromandel coast had moved to the west coast on account of war, inundation or persecution. The Christian community was reborn with the mass conversion of the paravās of the pearl fishery coast in $1536-1537$, but the new converts were left without a shepherd until 1542 when St Francis Xavier (1506-1552) landed among them with his relentless missionary zeal. Though mass conversions, with little preparation and no period of moral probation, continued under Xavier, he saw to it that his work was consolidated by his followers like Antony Criminali (1520-1549) and Henry Henriques (1520-1600), who were the first missionaries to master Tamil and familiarize themselves with the Tamil socio-cultural context (Neill 1984; Thekkedath 1982; Mundadan 1984).

The Madurai mission, started by Roberto de Nobili $(1577-1656)$ in 1606, is another milestone in the history of the Tamil church. Its significance lies in its approach to Tamil culture, its attention to the higher castes, and its location in the heart of Tamil country. It is said that within six months De Nobili had such a command of Sen-Tamil (classical Tamil) that he could engage in religious discussions with the learned men who visited him. Opting for sannyāsi dress and presenting himself first as a rāja rși, and later as a Brahmin sannyāsi, he initiated a new method of evangelization that was contested and opposed by other missionaries of his time. Amid opposition from within and without, wars, violence and famine the early missionaries (like Roberto de Nobili, Balthasar da Costa, St John de Britto, Costanzo Giuseppe Beschi) and catechists (like Muthudaiyan, Yesu Adiyan and Savarirayan) extended the Madurai mission to other parts of Tamil Nadu: Tiruchirappalli, Salem, the kingdoms of Thanjavur and Gingee, the provinces of Satyamangalam and Dharmapuri, the territory of the Maravas and the southern parts of Tamil Nadu (Thekkedath 1982). 
The impact of these missionaries on Tamil culture can be gauged by their contribution to Tamil literature. Henry Henriques, 'father of the Tamil press', is known for his Tamil grammar, Tamil-Portuguese dictionary, a Tamil version of Flos Sanctorum and catechism books. De Nobili, considered the 'father of Tamil prose', authored 20 works, the best being Ñanopadēsam (catechism) in five parts (Thekkedath 1982). Then we have the greatest innovator of Tamil literature, Giuseppe Beschi (1680-1747), whose Tèmbāvani, an epic on St Joseph, ranks among the most cherished classics of Tamil literature. Adaptation or the beginnings of inculturation of the Christian faith in the Tamil cultural context can be traced back to these fertile times of cultural missionary involvement (Subrahmanian 1981; Rajamanickam 1971, 1972a, 1972b).

The intense missionary activity of the 16th and $17^{\text {th }}$ centuries reached a point of stagnation and decline in Tamil Nadu at the dawn of the 19th century. But the spiritual renewal in the West reinvigorated the Christian communities in India, Tamil Nadu being a special focus of their missionary concern. The revival and expansion movements promoted by the Foreign Missions Society in Paris and the Jesuit province of Toulouse during the last two centuries was followed by the arduous task of creating a Tamil Christian community with its roots in the local soil. It began with the progressive Indianization of the leadership and the formation of local church structures. The efforts of the Christian communities to strike deeper roots in their native culture coincided with the Tamil renaissance. While contributing to the Tamil renaissance, Catholics and Protestants, missionaries and native Christians also sought to root the church more deeply in Tamil culture. The translation of the Bible into Tamil, the use of Tamil as the liturgical and theological language, production of devotional literature, poetry, hymns and lyrics, experiments with Dravidian art and architecture were all efforts to integrate the local culture with Christian life and expression. At present the situation of the Tamil communities is characterized by a drive to uplift marginalized and oppressed dalit Christians, a preoccupation with expressing their Christian faith in harmony with their culture, and a need to identify the close affinity between the two, going beyond the linguistic and political aspects of culture to reach its religious core (Grafe 1990). This attests the Christian community's eagerness to participate in the process of defining Indian identity and heritage.

In the attempt to restrict 'Indianness' to Hinduism there is a pervasive tendency to accuse the Christian tradition of having an alien origin and of being a prolongation of Western cultural colonialism. Sarkar $(2007,360)$ explains: "The charge persists, despite the fact that the origins of Christianity in one part of India (Kerala and Tamil Nadu) go back to the early centuries of the Common Era, preceding, incidentally, the conversion of England to Christianity and 
indeed the formation of most living forms of Hindu tradition." What is resented most is the Christian community's condescending attitude towards Hindu culture and religion, despite 'accommodation' attempts by Jesuit missionaries like Roberto de Nobili in the early 17th century and 'inculturation' efforts by Indian Christian communities since independence and the Second Vatican Council (in the case of Catholics). Notwithstanding the cultural and linguistic contribution of missionary and native scholars through the centuries, rooting Christian faith in the Indian cultural context and transforming unjust social structures like the caste system - to which in some ways Christian communities have succumbed - remain a challenge to be confronted squarely.

\subsubsection{Islam in the Tamil Cultural Context}

Like Christianity, Islam seems to have reached South India at a very early stage, that is, within a generation of the prophet's death. It is believed that a person named Cheramen Perumal, on his return from Arabia where he was converted to Islam by the prophet himself, built a mosque in his home town Cranganur near Cochin (Sherwani 1977, 141). During the next few centuries Arab settlertraders were to be found in most of the ports on the east and west coasts of South India. With the Roman trade declining, the Arab traders took over the supply of pepper and spices to the markets of Byzantium. "Unlike earlier traders linked to the Roman trade, the Arabs settled permanently in the coastal regions of the west and the south from about the eighth and ninth centuries. They were welcomed, given land for trading stations and left free to practice their religion, as had been the convention with Christians earlier in South India" (Thapar 2003, 332).

Long before the military conquests, by the 1oth century Muslim merchants had reached the major cities of the Deccan and North India. This is also true of the spread of Islam in the Ganges valley and in Gujarat in the 11th century through the work of wandering sufi, Muslim mystics from Yemen. The appeal of sufi masters was the offer of direct experience of God, like that propounded by the devotional Hindu bhakti traditions. "Their dialogue with the bhakti movement was to the advantage of both, as they questioned orthodoxy in their explorations of the meaning of religion and of the human condition" (Thapar 2003, 488; cf. Torri 2004, 180f).

The Venetian traveller Marco Polo (1254-1324) notes that the 'Saracens' of Tamil country used to go on pilgrimages together with local Christians to a little town in the province of Maabar where the body of St Thomas the Apostle was laid to rest (Marco Polo 1997, 232ff). The name 'Saracens' most probably refers to Tamil-speaking Muslims of Arab-Tamil descent, who believed that St Thomas was a Muslim and a great prophet (More 2004, 7). Marco Polo 
described these indigenous Tamil Muslim communities in the 13th century in a general way. Since the Arabs, Persians and later the Turks were not so much interested in the Tamil language and its literature, it was through the literature of these Saracens that Islam directly influenced Tamil culture. In his analysis of Tamil Muslim literature before 1835 (when printing was introduced in Tamil Nadu) More (2004, 58) notes: "though the literature produced by Tamil Muslim Sufis are [sic] not abundant, yet the biographies of the Sufis, written in Tamil or Arabic-Tamil, has [sic] a certain importance." Among Tamil Muslims sufi dargahs are so popular that they have a life of their own independent of the mosque-based traditions.

In the struggle for Indian independence, when the social activist Erode Venkata Ramasamy (1879-1973), born of a wealthy merchant family in Tamil Nadu, parted ways with the Indian National Congress by founding the Self-Respect Movement in 1925, Tamil Muslims were welcomed as part of the Dravidian fold. Together with the Tanjore School of Islamic Thought, spearheaded by B. Dawood Shah (1885-1969), this offered an opportunity for reforming Tamil Muslim society and participate in the struggle for independence and for the configuration of Indian identity and heritage (More 2004, 141; Torri 2004, 18off).

\subsubsection{Religion and Culture in the Struggle to Define Indian Identity and Heritage}

Indian heritage is logically linked to the Indian nation. India as a sovereign country recognized by other countries has a brief history of little more than sixty years. It gained independence from the United Kingdom in 1947 and became a republic in 1950. What is the heritage of this young state? And is it at all possible for such a vast country to speak of a partial overlap or even coincidence of geopolitical and cultural entities? Aloysius (1997) aptly sums up his interpretation of the long struggle that led to the independence of India in the title of his book Nationalism without a nation in India. This author shows how in the struggle against the colonial British rulers local forces were vying with each other to define Indianness or Indian heritage. A small elite who formed the Indian National Congress in 1885 tried to impose the Brahminic (ascriptive and hierarchical) tradition as the basis of nationhood and its identity. The vast majority of the lower castes, outcastes, tribal population, and religious minorities like Muslims, Sikhs and Christians saw this move by the elite upper castes as a clever ploy to re-establish their traditional hegemony, so much so that the majority of the underprivileged would have preferred the continuation of colonial rule rather than succumb again to the oppressive caste system with Brahmins in command. Thus the struggle for freedom implied defining Indianness in opposition to the colonizers, and for the lower strata of society and the 
minorities also in opposition to internal oppressors. In fact, the pre-independence period saw the emergence of other leaders besides Mahatma K. Gandhi: the claims of Muslims championed by S.A. Khan, Iqbal and M.A. Jinnah, and those of lower castes and tribal populations championed by J. Phule and B.R. Ambedkar. Regional leaders focusing on linguistic and ethnic differences also launched their own critique of Brahminic nationalism. The aforementioned E.V. Ramasamy (called Periyār, 'respected one' or 'elder' in Tamil by his followers) propounded his rationalist critique of Brahminic hegemony, taking his cue from the European Enlightenment and Buddhist rationalist tradition. Among these subaltern leaders there was "a search for a non-hierarchical religio-cultural framework either through a rediscovery of the different forms of nonBrahminical Hinduism, or by forsaking the whole of Hinduism itself or rarely, by taking to atheistic, rationalist ideologies" (Aloysius 1997, 77). As the author underscores: "The political awakening of the lower caste groups of the Indian subcontinent under the colonial rule was premised by an implicit (often also made explicit in the sayings and writings of the prominent leaders) vision of a new nation, of a new form of congruence between culture and power, and a new way of relating the self with the other" (Aloysius 1997, 83).

Paradoxically, the reforms set in motion by the British to bring traditional society into some congruence with the requirements of a modern political structure were seen by the elite group as "interfering with national religion with intentions of destroying national cultural legacy, traditions and civilization" (Aloysius 1997, 100). Such an attempt to identify Indianness with Hindu (here Brahminic) hegemony ultimately also led to the creation of Pakistan as a separate nation-state for Muslims under British India. Sikhs put up a similar struggle for an independent nation, Khalistan, even after the independence of India. The initial stage of this prolonged struggle can be traced back to the polemical work by Kahn Singh Nabha, Hum Hindu Nahin (We are not Hindus) in 1898 , and its tragic stage in the brutal assassination of prime minister Indira Gandhi by her Sikh bodyguards on ${ }_{31}$ October 1984 and the killing of thousands of innocent Sikhs in the riots that followed. In an in-depth study of the Sikh struggle Judge $(2005,72)$ affirms: "The trajectory of the Khalistan/militant movement followed the path of terrorism and its roots could be located in the way the Sikh identity has been politicized to control the religious affairs of the community." Politicization of religious identity leading to religiously motivated violence is undeniably the underlying thrust of Hindu nationalism, namely Hindutva ideology, which seeks to identify Indian heritage with Hindu (Brahminic) hegemony, thus branding other religious minorities like Muslims, Christians and Sikhs anti-nationals, communalists, sectarians or 'foreigners' (Panikkar 2001). 
It may be opportune to recall that initially the name 'Hindu' denoted a geographical rather than a religious identity. Before the arrival of Muslims the local religious communities referred to themselves as Vaiṣnavites, Śaivites, Lingayats, et cetera. "Communities of the subcontinent have in the past been diverse, with multiple identities, and the attempt to force them into unchanging, static entities would seem to contradict the historical evidence" (Thapar 2001, 3). Even Islam does not present itself in a monolithic manner. There are strong cultural and sectarian differences that can be traced back to their varying pre-Islamic past (cf. Thapar 2003; cf. Thapar 2014).

In his analysis of the origins and development of secularism and fundamentalism in India Cherian (2007) offers a panoramic view of these ideologies, which influence each other to a certain degree. Although the concept of secularism has its origins in the West, it has acquired a specific meaning in India because of the secular fabric that dates back to the time-honoured tolerance among theistic and atheistic currents of thought and communities. The religious tolerance that existed at the time of the two great rulers, the Buddhist Ashoka (3rd century BCE) and the Islamic Akbar (16th century), epitomises such a mind-set. As Ashoka's numerous edicts testify, he aimed at consolidating the empire on the solid ground of social ethics: "Of the basic principles, Ashoka emphasized tolerance. This, according to him, extended to tolerance towards people and towards their beliefs and ideas" (Thapar 2003, 202). In one of his edicts Ashoka affirms: "On each occasion one should honour the sect of another, for by doing so one increases the influence of one's own sect and benefits that of the other, while, by doing otherwise, one diminishes the influence of one's own sect and harms the other" (Major Rock Edict XII, tr. R. Thapar, cited in Thapar 2003, 202).

The modern Western view of secularism inspired by scientific humanism that advocates the separation of state and religion found its way into India via educational and juridical systems under British rule. However, it must be noted that there was a basic difference between the Indian and the European situation: "The Indian State did not have to struggle to free itself from the power of the Church but only to locate itself in relation to citizens who belonged to different religious denominations. In this context, the Indian State, right from the [sic] medieval times inherited, despite tensions and deviations, a political practice which respected the multi-religious character of Indian society. For instance, the administrations of both Hindu and Muslim rulers had a fair share of representatives from both religions" (Panikkar 2002, 53).

During the struggle for independence, in the face of the Hindu fundamentalist slant of some factions, other nationalists like Mahatma K. Gandhi (18691948) and Jawaharlal Nehru (1889-1964) laboured to create a secular democratic 
state in India. Gandhi, a deeply spiritual person, proposed a spiritual secularism based on Sarva dharma samabhāva (goodwill towards all religions). This concept did guarantee equality and tolerance for all religions. Nehru, a selfdeclared agnostic, advocated a nonreligious perspective based on science and socialism, guaranteeing equal rights and opportunities for all. In his view secularism was to be based on the social and political equality of every person. Hence a caste-ridden, gender discriminatory society was not really secular. In relation to religion secularism implies the equality of all religions and atheistic or agnostic worldviews. All religions are to be respected and no religion is to be favoured. Secularism as enshrined in the Indian constitution (articles 15, 16, $25^{-28)}$ entails the state's neutrality and impartiality towards all religions, distancing itself from all religions whilst recognizing the value of religion in society. Hence secularism in India does not imply an irreligious or anti-religious stand. On the contrary, as Sen $(2005,294-316)$ underscores, 'symmetric treatment' of religions can be the hallmark of a truly secular state in a religiously plural world. But such a secular stand, paradoxically, can also give rise to religious claims and clashes.

Religious conflicts are sometimes said to have their roots in modern secularism and traditional Hindu tolerance, since they facilitate conversion or crossing over to other religions. In India religious conversion may have political consequences and has actually led to social unrest in the past, so much so that some states have recently introduced laws to restrict religious conversion or have written government committee reports on the topic. Among these states are Madhya Pradesh, Orissa, Chattisgarh, Gujarat, Rajasthan and Himachal Pradesh. Potential laws are under discussion in Jharkhand and Uttarakhand (cf. Jenkins 2008). On 5 October 2002 the Tamil Nadu governor promulgated an ordinance prohibiting forced conversion. Article 3 reads: "No person shall convert or attempt to convert, either directly or otherwise, any person from one religion to another by the use of force or by allurement or by any fraudulent means nor shall any person abet any such conversion" (Tamil Nadu Ordinance no. 9 of 2002, art. 3). ${ }^{4}$ Mass conversions of Hindus to either Islam, Christianity

4 An explanatory statement on the ordinance by order of the governor states: "Reports have been received by the Government that conversions from one religion to another are made by use of force or allurement or by fraudulent means. Bringing in a legislation to prohibit such conversions will act as a deterrent against the anti-social and vested interest groups exploiting the innocent people belonging to depressed classes. It may also be useful to nip in the bud the attempts by certain religious fundamentalists and subversive forces to create communal tension under the garb of religious conversion. The Government has, therefore, decided to enact a law to prevent conversion by use of force or allurement or by fraudulent means." On the other hand government regulations like these could be seen as conservative intervention to maintain the status quo of socio-economic strata (cf. Fernandes 1999; Harriss 2002). 
or Buddhism are certainly not a recent phenomenon. Mathew (1982) gives a brief historical account of conversions in medieval times and in the period prior to independence. But more recently dalits in particular have become increasingly vocal about systematic maltreatment at the hands of high-caste Hindus and hope to overcome discrimination through conversion. Mass conversion, then, has become a form of collective protest against oppressive hierarchical social systems. In November 200150.000 dalits renounced their low-caste status in Hinduism and became Buddhists. Also famous are the controversial conversion ceremonies organized by the dalit activist and politician Udit Raj on 22 October 2002 and 6 December 2002 (the latter in Chennai), in which thousands of dalits converted to Buddhism, Islam or Christianity.

In the view of nationalist Hindus conversion is problematic and a hindrance to integration, denounced by them as indiscriminate and perfidious proselytism. $\operatorname{Kim}(2003,191)$ illustrates: "the debates associated with the Constituent Assembly, the Niyogi Report, the Hindu personal laws and the legislation on conversion in post-Independence India show that there was a cumulative and conscious attempt by nationalist Hindus to identify Indianness and Hinduness. The nationalist Hindu arguments that the assertion of Christian identity through conversion was a disturbing factor in forming a wider Indian identity assumed that Indian identity was a static and unified concept, and moreover somewhat 'neutral', so that all Indians could share it, regardless of their religious orientation. They argued that common identity as Indians must be based on the Hindu heritage, and in that the religious dimension was vital."

The underlying notion is that the growth of Christian communities through denationalizing conversions can alter the bedrock of Indian heritage and undermine the future of the nation. The accusation is that Christian communities take undue advantage of the non-proselytizing nature of Hindu religion, its spirit of tolerance and the national choice of secularism. The intricate nature of these allegations needs to be considered briefly.

The Hindu right wing has become increasingly wary of conversion, seeing its call for equality as a powerful attraction for the lower castes. Small wonder that the issue of religious conversion is not only associated with social emancipation, but also easily becomes intertwined with political interests, especially among movements advocating Hindu nationalism (cf. Harris 2002). Kim (2003, 187-190) even posits that traditional Hindu tolerance is more operational in its own sphere of influence than in religions like Christianity and Islam that do not share its overall vision and perspective on life and reality. But this might apply equally to other religious appeals for tolerance. The limitation of traditional religious tolerance exposes the need for a secular state that takes equal distance from all religions. At the same time the emergence of religious 
nationalism (e.g. in Hindutva ideology) attests that secularism in itself cannot guarantee neutrality towards religions. Because India is a deeply religious country where religion has great plausibility and social significance, some are convinced that secularism needs to be complemented with renewed understanding of the traditionally acclaimed virtue of religious tolerance as respect and recognition of the other along with commitment to one's own beliefs and values. Religious traditions can indeed be a power to promote social harmony, certainly when they are willing to explore the rich source material in their respective traditions that advocates tolerance and solidarity among all human beings (cf. Balasubramanian 1992; Casanova 1994; Herbert 2003, 86ff; Kim 2003, 189; Sterkens \& Hadiwitanto 2009, 8of; Fernandes 1999). What is called for is not just tolerance but respect and recognition of all religious traditions. "A willingness to receive from each other presupposes mutual respect and appreciation. The cultural inter-penetration witnessed during the last two thousand years was influenced by such a perspective. Even if this inter-penetration did not lead to an ideal synthesis, a cultural transformation imbibing elements from different streams did materialize. In almost all realms of cultural production, this inter-penetration occurred. In some, transformation is visible in form, in others content is enriched and in yet others, both form and content have undergone change" (Panikkar 2002, 57).

At the same time indiscriminate fusion of religious traditions may also give rise to conflictive situations as exemplified by the spontaneous syncretism of Islamic and Hindu traditions (Roy \& Rizvi 2003) among the Mehrat, Kathat and Cheeta communities of Rajasthan (reported by Jyotsna Singh on the B BC News website, 11 July 2008). Their mixed Hindu-Muslim identity, which permitted individuals to freely celebrate Hindu and Muslim festivals and worship both local gods and Allah, has been called into question by some organized Hindu groups (like Viswa Hindu Parishad) and Islamic groups (like Jamaat-eIslami), who feel that this confusion of religious identity must be rectified by a return or 'homecoming' (ghar wapsi) to the Hindu fold (according to the former group) or by proper education in their Islamic tradition (according to the latter).

The struggle to build a nation, to construct Indianness, to ensure unity in diversity continues. In this sense Indian heritage does not refer merely to the diversified ethnic, religious, cultural and linguistic traditions of the past but also to the project of integrating the best of these traditions through public reasoning and critique, avoiding homogenization of heritage in one form or another (cf. Sen 2005; 2006). 


\subsubsection{Nationalism, Fundamentalism and Religiously Motivated Conflict}

The emergence of nationalism in India dates to the colonial period. Nationalist movements and revolts challenged British rule with their aspirations to independence. In the 19th century there were a number of revolts against British rule, but they were localized. This changed after the revolt of 1857 , after which the number of nationalist movements grew. The first of these was the Wahhabi movement in the first half of the 19th century, begun under the influence of Shaik Muhammed ibn-Abdul Wahhad of Najd (Devasahayam 2007, 103ff). Hindu nationalism for its part began to emerge in the late 19th century, inspired by Hindu reform movements like Arya Samaj founded by Swami Dayananda Saraswati (1824-1883) and the philosophy of Bal Gangadhar Tilak (1856-1920), which emphasized the need for a reformed Hinduism while at the same time strengthening the common identity of its members (Berglund 2000, 178; Kuruvachira 2006, 7-44, 66-112).

As Smith (2003) sums up, the first coherent presentation of Hindu nationalism is found in the works of Vinayak Damodar Savarkar (1883-1966). Savarkar's writings are strongly anti-liberalism and aim at establishing Hinduism as a type of cultural nationalism. In his treatise Hindutva: who is a Hindu? (1923) he writes: "A Hindu means a person who regards this land of Bharatvarsha, from the Indus to the Seas as his Father-Land as well as his Holy Land, that is the cradle land of his religion" (Savarkar 2003, Frontispiece). His definition of Hindutva or 'Hinduness' further clarifies the ideology of Hindu nationalism: "Hindutva embraces all departments of thought and activity of the whole being of our Hindu race" (Savarkar 2003, 4). Accordingly Hindutva stands for a people united by a common country, blood, history, religion, culture and language. In other words, Hindus are more than a religious community: they are a nation. The ideas of Savarkar were developed further by Madhav Sadashiv Golwalkar (1906-1973), especially in his We or our nationhood defined (1939). Golwalkar was the second sarsanghchälak (supreme leader) of the Hindu nationalist cultural organisation Rss (Rashtriya Swayamsēvak Sangh), founded by Keshav Baliram Hedgewar (1889-1940) in Nagpur in $1925 .{ }^{5}$ Since the 1980 os India has seen a resurgence of Hindu cultural nationalism with strong political support and Hindu middleclass backing, also in rural India (Froerer 2007). Essentially

5 In the current political scenario the BJP (Bhäratiya Janata Party) comes close to the nationalism developed by Savarkar and Golwalkar. The political success of the BJP depends heavily on its alliance with two Hindu nationalist movements: the social organization vHP (Vishva Hindu Parishād or 'All Hindu Council') and the militant youth organization Rss (Rashtriya Swayamsēvak Sangh or 'National Corps of Volunteers') (cf. Van der Veer 1994; Nussbaum 2007; Fernandes 2007). 
Hindutva stands for a religio-political formula for Hindu cultural nationalism (Kuruvachira 2005; 2006). There are various theories to explain the rise of nationalism on the Indian subcontinent. Smith $(2003,182)$ summarizes the causes of nationalism as follows: ethnic unity comes to realize its geographical and historical unity and wakes up to national consciousness; modernization causes the nation to emerge; economic developments (industrialization) cause the emergence of the nation-state; and colonialism created the nation.

Most authors seem to concur that the foregoing explanations do not fit the specific historical and religious situation of India. According to Van der Veer $(1994, x)$ leading theories of nationalism tend to ignore the importance of colonialism and orientalism in the spread of nationalism. To understand nationalism in India we need an analysis of tradition (or religion) that is not prejudiced by the discourse of modernity. Most theories of nationalism are based on the distinction between modern society and traditional society. Nationalism is assumed to belong to the 'modern' side of this distinction (Van der Veer 1994, 17). Religion belongs to the 'traditional' side. The idea underlying the distinction is that religious nationalism will disappear as soon as society is truly modern. In the case of India the impact of modernity is different because of the colonial context in which it appeared. For example, Western discourse on individualism, equality and secularism combines with the influence of religion in the formation of the nation. There is also an orientalist impact on the way Indians perceive themselves. "The orientalists saw India as an ancient Hindu civilization, in which Brahmanical authority was paramount" (Van der Veer 1994, 20). They emphasized the decline of Hindu civilization under Muslim rule. This discourse was taken up by religious reformers (like Vivekananda), who called for a revitalization of ancient religion. Or, to put it differently: Hindu reform continues a discourse that has a pre-colonial tradition.

Following Van der Veer, we see an important role for nationalism in the transformation of religious identity in the colonial and post-colonial period. Van der Veer (1994, ix-x) argues that "religious identity is constructed in ritual discourse and practice; that these identities are not primordial attachments, inculcated by unchanging traditions, but specific products of changing forms of religious organization and communication; that religious nationalism articulates discourse on the religious community and discourse on the nation; and that Hindu and Muslim nationalisms develop along similar lines and that the one needs the other".

Rajamohan (2005) mentions the existence of revivalist and fundamentalist movements among Hindus and Muslims that tried to safeguard their religious practices against each other and from Christian missionaries long before the independence of India (1947). Paradoxically, the first illustrious victim of 
Hindu fundamentalism was the father of the nation, Mahatma Gandhi himself (1948). In recent times the communal conflict and violence between Muslims and Hindus reached a pinnacle all over India with the demolition of Babri Masjid at Ayodhya in Uttar Pradesh on 6 December 1992. Since then there have been bomb blasts and assassinations linked to fundamentalist groups on both sides (Smith 2003). In 2002 the state of Gujarat witnessed one of the worst clashes between nationalist Hindus and Muslims, leaving over 3.00o dead.

Sarkar (2001) provides a synthesis of the campaign conducted against Christians by Hindu fundamentalists. A tragic incident of violence against Christians took place at Monoharpur in the state of Orissa during the last week of January 1999: an Australian missionary Graham Staines and his two children were burnt to death in their vehicle by a mob led by Dara Singh, who was convicted in 2003. During the following years violence against Christians was perpetrated by Hindu fundamentalist groups in Goa (2006), Rajastan, Himachal Pradesh and Orissa (2007). Another wave of violence against Christian communities began in the Kandhamal district of Orissa with the assassination of Swami Laxmanandnda Saraswati and four of his close collaborators by tribal revolutionary Maoists on 23 August 2008. South India is generally considered fairly peaceful for Christian communities. Yet in 2010, 86 of the 152 attacks were in South India. In 2011 there were at least 175 attacks on Christian minorities in the following states: 45 in Karnataka, 25 in Orissa, 15 in Madhya Pradesh, 10 in Kerala, and six cases each in Chattisgarh, Uttar Pradesh, Andhra Pradesh, Maharashtra and Tamil Nadu. Panikkar (2001, xix) concludes: "The Christians have been foregrounded as another enemy, a new symbol, to demarcate the nation as Hindu."

Without going into detail, religiously motivated violence between Hindus and Muslims - in the analysis of Rajamohan (2005) - can be traced to the following causes: actual or perceived failure of mainstream political formation to reflect Muslim aspirations; frustration among the youth due to unemployment and lack of opportunities for higher education; poor living conditions; organization of trade and commerce on communal lines; financial incentives and indoctrination by radical religious organizations. Similarly, in the conflict between Hindu and Christian communities the cause seems to be the conversion of dalits and tribal persons that transforms their oppressed social status - determined by the caste system - and empowers them to stand up for their rights and have access to education and development.

At the time of our survey (2004) the situation in India was quite peaceful, particularly in Tamil Nadu. However, as described above, conflict among religious communities existed before and continues to erupt in various states, particularly in the north of the subcontinent. The absence of religious conflict and 
violence does not mean that it has been completely eradicated. If the subtle factors in peaceful situations that bear the seeds of conflict are not identified and dealt with appropriately, there is no guarantee that this dormant state may not suddenly explode. According to Panikkar (2002) the educational environment can play an important role in nurturing either conflict or harmonious interpenetration. In his aptly titled book on communalism, Before the night falls, Panikkar underscores the urgent need to examine this field. Not surprisingly, therefore, this research focuses on students in higher education.

\subsection{Research Problem: Religion and Conflict}

\subsubsection{Causes of Interreligious Conflict}

The word 'conflict' in itself does not refer to a negative situation, for conflicts can be constructive or destructive (Varshney 2003, 282). Conflicts can be a powerful source of socio-cultural innovation or turn into an escalating force of violence and annihilation. Alongside progress in knowledge, science and technology, violent conflicts have frequently marked and marred human history. There is no gainsaying that the world religions have played their constructive and destructive role in a conflict-ridden world. In this section we focus on the underlying correlation between religion and conflict, both constructive and destructive (cf. Kurtz 2007).

For the sake of clarity we use the definition of conflict by Lincoln (2003, 74): conflict refers to "[...] the situation that arises when rival interests can no longer be contained by the structures and processes ordinarily competent to do so". This definition clearly distinguishes situations of conflict and violence, while at the same time claiming that situations of conflict have the potential of becoming more overt, confrontational and violent. Rival interests between religious groups or communities can refer to material resources like territory, wealth, education, positions of power and socio-economic advantages, but also to nonmaterial resources like dignity, prestige and all forms of symbolic capital. Rival interests are considered to be the cause of conflict between religious groups: they 'fuel' religious conflicts. In our research we distinguish between four causes of religious conflict: socio-economic, political, ethniccultural and religious. Each cause represents an interest of religious groups, that is something valued by the group. In the case of socio-economic and political causes this interest concerns scarce material and non-material resources. In the case of ethnic-cultural and religious causes it concerns group identification (also see chapter 7). 
To obviate the potential threat of outbreaks of violence we need conflict management. In religious conflict transformation we distinguish between three dimensions: conflict management, conflict resolution and post-conflict structural reform (Appleby 2000, 210). Conflict management aims at preventing the conflict from becoming violent. Conflict management typically focuses on raising awareness of the causes of conflict in order to eliminate or ameliorate them (Appleby 2000, 214). For example, religious leaders can play the role of advocates for the oppressed or criticize certain structures in society which are unjust to specific ethnic-religious groups. Or religious communities can act as safe havens for dialogue between different groups in society. Conflict resolution aims at removing the inequalities or sources of conflict between religious groups or communities as far as possible. There are various nonviolent means to remove the sources of conflict, such as mediation, negotiation and/or advocacy on behalf of one or more parties to a conflict. Finally there is the dimension of post-conflict structural reform aimed at the restoration of productive social relations and political stability (Appleby 2000, 220). In order to transform a conflict into a peaceful situation it is not enough to eliminate the cause of conflict. Besides this, we need to create a situation of cooperation, trust and stability between different groups in society.

We focus on interreligious conflicts, that is conflicts between religious groups that are to a certain degree encouraged by a religious community or inspired by a religion. Following Max Weber, we think that religion belongs to the order of communal actions (Kippenberg 2008, 23). Religious conflicts are always the acts of individual persons, as in the case of religious terrorism. But we regard these acts as embedded in a shared concept of the self and the world and grounded in a social reality.

Finally, interreligious conflicts can be an actual or a latent reality in the lives of people. To study people who are in actual conflict is very complicated, not only practically but also ethically. On the other hand, the study of latent religious conflicts may raise the objection that it need not lead to actual conflict in a socio-historical context. Taking up the latter perspective, we study the perceptions of members of religious communities regarding the causes of conflicts. What makes it scientifically and practically interesting to understand religious people's perceptions of interreligious conflicts? Latent religious conflicts refer to the meaning members of a religious community attach to certain states of affairs or actions in the socio-cultural fabric. Which state of affairs or actions potentially lead - in their perception - to conflict? What may trigger anxiety, disintegration, even violence between religious groups in society? Perceptions are subjective, that is related to the meaning system of religions (or religious communities). And that is precisely what makes a study of the ideas 
that members of religious communities have about causes of religious conflicts so interesting (Kippenberg 2008, 13). It affords insight into the way religious people look at a certain state of affairs in society, and the potential hazard it poses of conflict between religious groups. Religious conflicts are not objective descriptions of situations but are influenced by people's perceptions grounded in communal ideas of religions. As stated above, at the heart of religious conflicts are rival interests between groups in society. What may be a strong interest for one group in a specific socio-cultural situation may not be so for another religious group. And this is precisely what makes the study of latent religious conflicts scientifically interesting and practically relevant.

\subsubsection{Predictors of Perceived Causes of Interreligious Conflict}

What influences the perception of religious conflicts of members of religious communities? We assume that perceptions are influenced by the (re)definition of the social identity of the religious persons as well as the (re)articulation of their religion's claims to authority in a situation. To put it bluntly: what is at stake in a religious conflict is their very social identity as religious persons and the value of their religion. This assumption is not shared by all scholars in the so-called 'religious violence debate'. Many scholars focus on the following characteristics of religious conflicts (cf. Sidel 2007, 7-13). In the first place, religious conflicts are acts of direct physical violence against more subtle but no less powerful forms of coercion and structural violence. Secondly, certain forms or instances of violence are attributable to specific religions while others pertain to religion in general. Thirdly, they suggest that the 'religious' character of conflicts is based on some de-contextualised pre-understanding of specific religions; that is, religion is often presented as a disembodied system of belief. Such an understanding of religious conflicts seems to ignore or exclude some important aspects relating to the identity of the religious actors involved. Not only religious institutions but also religious identities play a role in the conflict that ensues. And religious identity not only informs the (perception of) religious conflicts; the effect of a conflict (with or without acts of violence) is to create religious identities and boundaries, whether between bodies of believers, between recognized religious faiths or between an orthodox definition of faith and a heresy'. Fourthly, religious conflicts need to be compared with other forms of societal conflict (e.g. ethnic conflict) so as to understand their specifically religious character.

In contrast to the (dominant) position formulated above, we assume that the (re)definition of social identity and (re)articulation of claims to authority by (one's own) religion are the main sources of the perception of religious conflicts in heightened states of uncertainty and anxiety (Sidel 2007, 16ff). In brief, 
we assume that a religious conflict is not just a reflection of the strength of religious identity. It is not the difference between people but the loss of difference that gives rise to violence (Girard 2007). The sociologist Tilly $(2003,77)$ draws the same conclusion in his survey of collective violence in modern history: "Violence generally increases and becomes more salient in situations of rising uncertainty across the boundary." In contexts of uncertainty and anxiety about religious identities and their boundaries conflicts between religious groups can erupt. In a context of uncertainty the (re)definition of the self and claims to authority are achieved through violent opposition to an antagonistic other and through recognition in the symbolic order of society. People need recognition by others in society in order to find their own identity (cf. Taylor 1994). Identity is not a fixed and stable set of characteristics of groups or individuals, but an unstable and interactive complex related to other identities in a socio-cultural context. Religious conflicts need to be understood not only as (re)actions by individuals or groups towards a perceived threat to some material or nonmaterial interest, but also implies an anticipated response by audiences involved in this conflict. Conflicts need to be viewed in a broader process of discursive and social formation, in which religion plays a prominent role. Conflict must not only be understood in terms of its destructive consequences, but also in light of its constructive effects. Religious conflicts reflect the emergence of new kinds of threats to religious identities as well as shifting circumstances in which such identities could be reconstituted and reasserted.

In our research we view religious identity through the lens of the religious meaning system. A religious meaning system operates in much the same way as any other meaning system. It is "similar to other systems in structure, malleability and functioning, yet is unique in centering on what is perceived to be the sacred, and in the comprehensive and special way in which it can serve to fulfill the quest for meaning" (Silberman, Higgins \& Dweck 2005, 764). In a meaning system we can distinguish between two domains, each with three elements: the domain of descriptive beliefs, which include a theory of the self; a theory of the world, contingencies and expectations; and the domain of prescriptive beliefs, which include beliefs about (life) goals, actions and emotions. Or, put in question form, meaning systems provide answers to the following six questions: Who am I? What is the nature of the world? What can I expect from my relatedness to others and to the world? What should I strive for? What should I do? What should I feel? This idea of a religious meaning system comprising descriptive and prescriptive beliefs is comparable to Clifford Geertz's (1973) distinction between 'models of reality' and 'models for reality' in religion as a cultural system. Readers familiar with the theory of Geertz can keep this in mind when we refer to the religious meaning system. Religion functions as a 
model of reality when it helps people to apprehend the nature of reality by providing conceptions of the world, the self, and the relations between them. In models for reality, religion determines people's actions by providing mental dispositions which establish powerful, pervasive and long-lasting moods and motivations (Geertz 1973, 123). Yet, the concept of religious meaning system avoids some of the critique on Geertz's concept of culture as abstract and antipsychological (Pyysiainen 2001, 44-53).

\subsection{Research Questions}

Our cross-religious comparative study seeks to identify predictors of the ideas of college students in Tamil Nadu about causes of religious conflict. In describing these predictors we make a distinction between Christian, Muslim and Hindu college students. We selected four religious variables as predictors of causes of religious conflicts: religious practices, mystical experiences, attitudes towards religious plurality and religiocentrism. The four religious variables will be analysed in chapters $3-6$. For each religious variable we formulated the following questions:

(1) What comparative understanding of the religious variable concerned emerges among Christian, Muslim and Hindu students once groupspecific differences have been ascertained?

(2) Are there significant differences in levels of agreement with the religious variable concerned between Christian, Muslim and Hindu students?

(3) Which personal (socio-cultural, socio-economic and socio-religious) characteristics of Christian, Muslim and Hindu college students relate to the religious variables?

(4) Which personal characteristics of Christian, Muslim and Hindu students may be considered predictors of the religious variable?

We make a cross-religious comparison of the scores on religious variables insofar as the constructed scales allow. We check (by means of a Scheffé test) whether the cross-religious differences, if any, between Christians, Muslims and Hindus are significant. Do our religious groups differ in their level of agreement with the attitudes or ideas which we think are predictors of causes of religious conflicts? Next we study the association between the level of agreement with these attitudes/ideas and background characteristics of religious students. What is the social location of the ideas/attitudes of the students? 
This affords insight into the influence of context on students' agreement with the causes of religious conflicts. Finally, we want to know which characteristic is decisive in explaining the level of students' agreement with the ideas/attitudes. We make separate analyses of Christian, Muslim and Hindu students to establish whether there are differences in contextual influences between the three groups.

The research questions with regard to the dependent variable (i.e. causes of latent religious conflicts) are the following:

(1) Which comparative models of causes of latent religious conflict are discernible in the perceptions of Christian, Muslim and Hindu students?

(2) Are there significant differences in agreement with causes of latent religious conflicts among Christian, Muslim and Hindu students?

(3) Which personal (socio-cultural, socio-economic and socio-religious) characteristics and religious ideas relate to causes of latent religious conflicts among Christian, Muslim and Hindu college students?

(4) To what extent can agreement with causes of religious conflicts among Christian, Hindu and Muslim students in Tamil Nadu be explained by descriptive beliefs about the relationship between self and others and prescriptive beliefs about religious actions while controlling for students' personal (socio-cultural, socio-economic and socio-religious) characteristics?

The first three questions are descriptive and will be examined in chapter 7 . The fourth question is explanatory (see chapter 8).

\subsection{Research Variables}

What attitudes and convictions are involved in our research into causes of latent religious conflicts? We start with the dependent variable and the intermediate variables. Next we describe the independent variables. The dependent and intermediate variables will not be probed in depth, as they are dealt with in separate chapters. We only give a description of the independent variables. They can have a direct or an indirect effect on the dependent variable (also see section 8.3.4). The independent variables map the personal circumstances in which people may (or may not) experience higher levels of uncertainty and anxiety (see section 1.3.2). 


\subsubsection{Causes of Religious Conflicts}

The dependent variable in our cross-religious comparative research are causes of religious conflicts. We distinguish four causes: socio-economic, political, ethnic-cultural and religious. Each cause expresses an interest of religious groups. In the case of socio-economic and political causes this interest concerns material and non-material scarce resources. In the case of ethnic-cultural and religious causes it concerns group identification (also see chapter 7 ).

\subsubsection{Religious Meaning System}

The intermediate variables are beliefs in the religious meaning system. We selected two descriptive and two prescriptive beliefs which are predicted to influence our religious respondents' ideas on causes of religious conflicts. The two descriptive beliefs reflect religious notions about the relationship with other religious groups. The first is the interpretation of religious plurality (see chapter 5). How do religious students see the existence of other religions in society? Do they want dialogue with persons of other religions in order to be enriched by their ideas about God? Or do they regard the existence of other religions as irrelevant because absolute truth can be found only in their own religions? The second belief is called religiocentrism (see chapter 6). What is the attitude of religious students in Tamil Nadu towards members of their own religious group and towards members of other religious groups? Do they regard members of their own group positively (positive in-group attitudes)? And how negative are they towards members of other religious groups (negative out-group attitudes)? Religiocentrism is strong when a person has a highly positive in-group attitude combined with a highly negative out-group attitude. One can expect that religious persons who strongly agree with religiocentrism will have a higher level of agreement with causes of religious conflicts than those who are less religiocentric, because the former regard the religious identity of members of other religious groups as highly negative.

We distinguish between two prescriptive beliefs. The first is beliefs about religious practices that persons should engage in according to their own religion (chapter 3 ). We expect religious persons who are more involved with the prescribed practices of their own religion to be more committed to that religion. When their religious identity (as expressed in participation in religious practices) is strong, they will be more inclined to defend the interests of their own religious group. Hence there will be greater agreement on causes of religious conflicts. The second prescriptive belief is mystical experience of God that is highly valued in a person's life (chapter 4). Mystical experiences are considered a universal human possibility in all religions. We predict that religious persons who agree strongly with mysticism will agree less about causes 
of religious conflict. This is because members of other religious groups can have the same (highly valued) experience of God as their co-religionists. In that case they will be less inclined to see their own identity as conflicting with the identity of members of other religious groups.

\subsubsection{Socio-cultural Characteristics}

Socio-cultural characteristics that might influence 'force-driven religious conflict' directly or indirectly are age, gender, language, urbanization and field of specialization.

Age is measured in three categories: $17-19$ years; $20-22$ years; and $23-26$ years. We asked about age because religious opinions change over different generations and even age groups. As in many other countries, in India older people are more religious than younger ones. Even in the youthful group one could expect opinions on interreligious relations to change as a result of personal experiences.

Gender simply indicates whether the student is female or male. Past studies have consistently shown that there are differences in the religiosity of women and men. Not only do women generally tend to be more religious and more religiously committed than men, but substantive differences have been observed as well (e.g. Nelsen et al. 1985). Possible explanations for these gender differences are common in the literature. Socialization theories and structural location theories concentrate on social and contextual influences, which shape the different responses to religion among women and men. Other theories concentrate on personal or individual psychological characteristics which differentiate between women and men, like depth psychology theories, personality theories and gender orientation theories (Francis 1997). While attempts to isolate socialization effects on gender differences in religiosity have largely failed, 'gender orientation theories' or theories based on physiological differences between women and men are gaining support (cf. Stark 2002; Roth \& Krol 2007). Although we do not dwell on explanatory discussions of gender differences, it obviously makes sense to control for differences between women and men. This is all the more important in a study focusing on relations between different religious traditions. When it comes to interpersonal relations there is growing evidence that women are more open to 'the other' than men (Markus \& Oyserman 1989). Differences between men and women are also likely to be influenced by the surrounding cultural atmosphere: the gender status gap is exceptionally big in India. India is infamously second on the list of countries disadvantageous to women. India has shocking statistics on sex ratios with a disproportionately higher number of births of boys since the early 1980s. These figures illustrate the enormous gender status gap in India. The 
increasing proportion of males is attributed to several factors, the major ones being geographical patterning of differences, religion and socioeconomic status. Preponderant male birth rates are as high as 136 boys to 100 girls in certain districts, particularly in the west of the country from Punjab to Maharashtra. The 2011 census birth sex ratio in India was 109.1 boys to 100 girls (i.e. 917 girls for 1000 boys). Surprisingly, sex ratio imbalance of births also correlates with religious background, the biggest excess of male birth being among Sikhs (129.8 boys against 100 girls) and Jains (118.0), followed by Hindus (110.9), Muslims (107.4) and Christians (103.8) in 2001 (Guilmoto 2007, 8; Hvistendahl 2011, $5 \mathrm{ff}$ ). And once life has begun, India shows excessive female child mortality, whereas excessive male mortality is the biological norm and characterizes most developed and underdeveloped countries (Lopez \& Ruzicka 1983; Kishor 1993). In the 2011 census the child sex ratio (group o-6 years old) in India was 919 females per 1000 males (i.e. 109.4 boys against 100 girls, to permit comparison with the figures above), which is the lowest sex ratio since 1961 and a considerable fall of the number of girls compared to 2001 (sex ratio of 927 for $0-6$ years old in 2001). ${ }^{6}$ Tamil Nadu shows more balanced statistics with 946 females per 1000 boys in the $0-6$ years old category (Gopalakrishnan 2011). Nevertheless, these hard figures are sufficient reason to make gender a variable in dealing with our Tamil Nadu research population, and to expect gender differences in regard to religious practice, mysticism, models of interpreting religious plurality and religiocentrism. When it comes to explaining agreement with force-driven conflict, there are additional reasons why we control for gender. Men show higher levels of social dominance orientation than women (Sidanius et al. 1994), and this gender difference does not vary with the size of the perceived status gap between men and women (Levin 2004). Moreover, some authors indicate that women and men tend to deal differently with ethnic and religious conflicts (cf. Butalia 2001; Skjelsbæk \& Smith 2001).

Since language "is the reservoir of tradition and the medium in and through which we exist and perceive the world" (Gadamar 2008, 29), we asked our respondents to state their mother tongue. The questionnaire offered the following response options: Tamil; Telugu; Malayalam; Kannada; Urdu; or "any other ...", with the possibility of filling in a language of their choice. However, we ended up by dividing our respondents into two groups: those who give Tamil as their mother tongue and those who don't. Speaking Tamil can be considered an indicator of knowledge of and integration with the local Tamil culture. Tamil is one of the Dravidian languages belonging to the 'Southern group' and, like all Dravidian languages, is rich in kinship organization. Studies like those of

6 See http://www.censusindia.gov.in. 
Ramaswamy (1997) and Krishnamurti (2003) illustrate the big impact of language use on both social organization and religious sentiments in Tamil Nadu. Hence we expected it could be relevant to the religious elements described in chapters $3-6$. Whether this was proved empirically in our survey will be discussed later.

Urbanization is measured in three categories and indicates whether respondents spent at least three quarters of their life in a village, town or city. This was computed as follows. Students were asked to specify how many years of their lives were spent in villages, towns and cities. In combination with their age, we computed where they lived longest (e.g. $3 / 4$ of their lives). The small number of students who lived for longer periods in different places with different degrees of urbanization (and did not reach $3 / 4$ of their lives in any of these categories) were assigned a 'missing value' on this variable. We thought this socio-cultural characteristic important, since degree of urbanization is an indicator not only of modernization and economic development that influences religiosity but also of the likelihood of contact with people belonging to other religious groups. Moreover, urbanization has been associated with the consolidation of communities along religious lines (Singh Sandu 2003; Jha 2011, 18).

Field of specialization is measured in two broad categories: arts and social sciences $(=1)$ and natural sciences $(=2)$. From previous research (Guimond \& Palmer 1996; Sterkens et al. 2010) it is known that choice of a field of study is a significant factor in the social location of types of religious identification, religious convictions (e.g. radicalism), religiocentrism and political convictions about intergroup relations. Faculties of disciplines in which religion is likely to be studied (e.g. arts and social sciences) have been found to be less religious than faculties of disciplines in which religion is not studied (e.g. natural and life sciences) (Lehman 1974). Hence we took this into account as well.

\subsubsection{Socio-economic Characteristics}

A second set of student characteristics concerns their socio-economic status. For a study conducted in India, it is surely not surprising that we include the respondent's caste as an important socio-economic characteristic. Below we explain exactly what is measured by 'caste' in this research and how to interpret it. We also asked for the highest educational level attained by both parents of the respondent.

What do we mean by caste in this research? And how do we legitimately measure it? Obviously our study is too limited to reflect the complexity of the thousands of existing traditional jätis or even the more limited system of varnas in Indian society. Besides, for a quantitative survey of this kind it would be inappropriate, if not illegal to ask about this type of caste as a background 
characteristic. As early as the Lex Loci Act of 1845 and the Caste Disabilities Removal Act of 1850, restrictions with regard to occupation and other types of discrimination resulting from the traditional caste system were declared illegal (cf. Rodrigues 2006, 60-65). The classical divisions of Hindu society that can be traced back to the Rg-Veda (x, 9o) comprise four castes (varnas): Brāhmana (priestly caste), kșatriya or räjanya (military caste), vaiśya (landowners and merchants), and súura (cultivators and menials). Although its original intention was to ensure harmony in the complex social fabric, the caste system gradually degenerated into a divisive and discriminatory force. Based on the division of labour, castes later comprised groups engaged in various professions, which gradually became hereditary. In time the great variety of occupations gave rise to numerous subcastes (jätis), which were not strictly hierarchical. The systems of varnas and jätis still coexist and overlap to a certain degree, but it should be noted that the connection between the jāti system and Hinduism is complicated, certainly not a one-to-one relationship (Dumont 1980; Quigley 2005). We do not dwell on the details of this complex phenomenon.

In the contemporary context, although the Indian constitution formally condemns the caste system as untenable, the government recognizes that social inequalities are partially attributable to the hegemony of the caste system. With a view to rectifying the socio-economic imbalance the government has introduced the strategy of 'reservations'. This policy facilitates entry of grossly underrepresented groups into the educational and professional fields. Paradoxically, among other criteria such as religion and gender, caste serves as a basic criterion for the identification of underprivileged classes (Hasan 2009). The Indian constitution (articles 341, 342) identifies 'scheduled tribes' comprising over $24 \%$ of the Indian population, and 'scheduled castes' as groups who have historically suffered oppression and denial of equal opportunity. The government proposes to reserve a certain percentage of jobs in the public sector for 'scheduled tribes' $(7,5 \%)$ and 'scheduled castes' (15\%). Later reservations were introduced for 'other backward castes' (Constitution article 340). The detailed division of castes and the percentage of job reservations vary from state to state. In Tamil Nadu a further distinction has been made since 1971 between 'most backward castes' and 'backward castes'. Currently Tamil Nadu reserves $69 \%$ of posts for about $87 \%$ of the population. Paradoxically, this 'positive discrimination' revives the illegal caste system in a new form. Because of its widespread use in government policies people generally know to which of these categories they belong.

In our research we followed the classification used by the Tamil Nadu government: 'scheduled tribes' (ST) are traditionally identified with adivasi 
(original indigenes); 'scheduled castes' (sc) are identified with dalit (untouchables and outcasts). 'Most backward castes' (MBC) and 'backward castes' (BC) are consequently the better end of the disadvantaged groups. Those who do not belong to these categories and cannot claim reservations are said to belong to the 'forward castes' (FC). We also included the category 'other castes' (OC), since there may be respondents who do not associate themselves with these categories. The latter category was chosen by very few respondents and was eventually coded as a missing value. We also found very little difference between the general characteristics of people who classified themselves under 'scheduled tribes' and those who said they belonged to 'scheduled castes'. Consequently we recoded these two categories as a single category. We ended up with four categories on the socio-economic ladder. From low to high they are: 'scheduled tribes and scheduled castes' ( $\mathrm{ST}+\mathrm{SC})$ ); 'most backward castes (MBC); 'backward castes' (BC); and 'forward castes' (FC).

Father's and mother's educational level is measured in three categories: no formal education or primary education; middle or high school; and secondary school, undergraduate or higher level education.

\subsubsection{Socio-religious Characteristics}

Socio-religious characteristics concern our respondents' religious socialization. Socialization can be described from two perspectives: that of the society acting upon the individual (objectively), and that of the individual responding to the society (subjectively). On the objective plane socialization is "the process by which the society transmits its culture from one generation to the next and adapts the individual to the accepted and approved ways of organized social life" (Fichter 1973, 29). The accent here is on individuals, groups and institutions that transmit systems of meaning, values, symbols, roles, et cetera. On the subjective plane socialization is "a process of learning which goes on in the individual while he is adapting to the people around him" (Fichter 1973, 30). The emphasis here is on individuals' social learning and their construction of religiosity in a process of adaptation to the environment.

Without losing sight of these twofold perspectives, we briefly examine the role of principal agents of religious socialization: family; peers; religious community; educational community; and media (Berns 2003; cf. Bajzek \& Milanesi 2006, 72-83; Cornwall 1989).

The family is the place of primary socialization. Parents play a key role as identification models. However, the family's role in religious socialization is determined by the significance of religion in society. In a traditional context where religion has a central place and where the family itself is well integrated with the religious structure religious socialization is to a great extent delegated 
to the family. But in a secularized context where religion loses its central place in society religious socialization in the family might become ineffective. In such contexts religious socialization in families is still a (quite) necessary but certainly not sufficient condition for religiosity. The attempts (if any) made by the family are easily neutralized by other socializing agents (cf. Vermeer 2010; Sterkens \& Vermeer 2012).

The peer group - which allows for more egalitarian, reciprocal interaction - has emerged as an important socializing agent among contemporary youth. It provides a place of transition from the family nucleus to today's complex, competitive society. As a spontaneous group it can play a positive role in religious socialization, yet in a cultural context of fragmentation and secularization the peer group can distance itself from institutionalized religion, preferring more individualized forms of religiosity.

The religious community becomes more important for religious socialization when family and peers hardly feature in religious socialization. Religious socialization by religious communities entails nurturing the personal commitment of the young through religious initiation and education. In minority religious communities - as is the case with Christians and Muslims in Tamil Nadu and in India as a whole - such religious socialization risks creating a ghetto mentality that cuts off the young from other religious traditions in the wider society.

Young people today spend a good deal of their time in educational institutions: schools, colleges and universities. The socialization that takes place in dealings with other students, teachers, professors, associations, et cetera allows them to transcend their emotional ties with the family. Religious socialization in formal education depends on the centrality or marginality of religion in society at large and - more specifically - on the place of religion in the curriculum. In multi-religious contexts state schools tend to accommodate the dominant religious tradition, whereas in secularized societies they may exclude religious education altogether (Fox 2008, 158, 198f, 207; Ziebertz \& Riegel 2009). In such contexts religiously affiliated schools which explicitly aim at religious socialization run the risk of - unintentionally - promoting religious segregation. Especially in minority contexts religiously affiliated schools experience a double challenge: to contribute to the flourishing of their own religious tradition, and to stimulate interaction with and full participation in the surrounding society (Yusuf \& Sterkens 2014).

The growing importance of the mass media in socialization is evident from the signs of crisis in other agents of socialization. In a way the mass media modify the authority of other agents of religious socialization. The contribution of the mass media to religious socialization, too, is determined by the 
place of religion in society. In a secularized society the mass media tend to marginalize religious information. In a democratic and religiously plural country like India they pay particular attention to the dominant religion, allowing some room for minority religions as well. Minority religions in their turn seek to use the mass media to cater for religious socialization of their own followers and to expand their sphere of influence in society. The mass media also enable religious minority groups to be part of their worldwide communities. Hence they play an ambivalent role in religious socialization. They can moderate the role of traditional agents of religious socialization by either diminishing or strengthening them. They can also put religious socialization in a global perspective.

The theory of Schlenker $(1985 ; 1986)$ on the public and private self sheds further light on how these agents of religious socialization influence the young, particularly their subjective learning or the way they construct their own identity. According to Schlenker $(1986,22)$ the private and public selves are complementary facets of an individual's identity. He defines identity as "a theory of self that is formed and maintained through actual or imagined interpersonal agreement about what the self is like" (Schlenker 1986, 23). "People's ideas about themselves are expressed and tested in social life through their actions. In turn, the outcomes of these 'tests' provide a basis for crystallizing, refining, or modifying identity based in part on how believable or defensible these identity images appear to be" (Schlenker 1986, 24). Individuals construct their identity through repeated interaction with the same people over a considerable length of time. Based on this interaction they construct their "desirable identity images", which "represent what people believe they can be and should be in particular contexts, and are influenced by personality factors, situational factors, and audience factors" (Schlenker 1986, 25). Speaking of audience, Schlenker distinguishes between three types. The first is the inner self, that is the internalized values, standards and knowledge which provide a basis for selfevaluation. The second type of audience consists of people with whom one interacts directly. The third type is the so-called 'reference others'. These are people whose opinions and standards are sufficiently respected to function as exemplars and evaluators across a wide variety of situations independently of direct interaction. Parents, close friends, admired mentors and the like can all function as reference others.

The instrument for measuring the impact of agents of religious socialization as 'reference others' is based on the distinction between the agents of religious socialization: family (mother, father, close relatives), peer group (close friends), religious community (religious leaders, religious groups or associations outside educational institutions), educational community (school teach- 
ers and college professors who provide religious or moral education, religious groups or associations within the school and college setting), and the mass media (religious figures appearing on TV or radio programmes). The respondents were asked to indicate whether these agents of religious socialization had played an unfavourable or a favourable role in their understanding and practice of religion on a four-point Likert scale ranging from very unfavourable (1) to very favourable (4). A complete list of items appears in appendix B.

\subsection{Sampling and Data Collection}

For the purpose of our research we saw fit to focus on college students, since they have to play a leading role in society as a whole and in their own cultural and religious communities. In due course they should join the ranks of the elite in all spheres of society: science, the arts, public media, the economy, government, et cetera. Hence knowing how they interact with peers in other religious traditions can tell us something about the dynamics of the correlation between religion and conflict in present-day society and provide some clues to its development in the near future.

According to the current Statistical handbook $(2011)^{7}$ of the Tamil Nadu government this state has a total of 587 colleges for general higher education (arts and sciences) attended by over 700.000 students. Of these, 62 are government colleges and 9 are university constituent colleges; 133 are subsidised (aided) colleges run by Christians, Muslims and other minority communities; and 383 are self-financing. ${ }^{8}$ Our research population consisted of all students attending colleges for general education in the federal state of Tamil Nadu, India. As clarified below, a selective stratified sample, taking into account gender, religious affiliation, area of residence and educational level, was drawn from 16 colleges and the University of Madras.

Given the relevance of gender difference to our theme, eight women's colleges were selected, the remaining eight being principally for men (some of which have admitted small numbers of women in recent years). The University of Madras, by contrast, has a fully fledged coeducational system.

7 See http://www.tn.gov.in/deptst/Education.pdf (28 April 2014).

8 At the time of the research there were 441 colleges for general higher education (arts and sciences) attended by over 459.000 students. Of these, 60 are run by the state, 134 are subsidised colleges run by Christians, Muslims and other minority communities, and 247 are self-financing. 
From the perspective of the religious affiliation of educational institutions, the University of Madras and two government colleges were chosen to represent the category of secular higher educational institutions, although the great majority of students are Hindus. Since only a few (six) of the aided colleges have an explicit Islamic affiliation, we chose two of them. Muslim students are generally concentrated in Muslim colleges. Among the 32 colleges explicitly affiliated to Christian communities, eight Catholic and two Protestant colleges were chosen. This was because we can expect no more than an average of $25 \%$ of students at Catholic colleges to be Catholics, whereas Protestant students tend to be concentrated in denominational colleges. Among the aided colleges at least 42 had an explicit Hindu orientation. We chose only two Hindu colleges, since Hindu students constitute a great majority in both public and Catholic colleges. We did not include self-financing colleges in our sample, since aided colleges represent the religious thrust and government colleges the secular thrust in education more adequately. Besides, some of the aided colleges also have self-financing departments.

Since colleges are generally concentrated in urban areas and particularly in the state capital, we selected ten colleges and the University of Madras in Chennai, and three colleges in the other three major cities, Coimbatore, Tiruchy and Madurai. To complete the picture we included three colleges in semi-urban areas: Tirupattur, Cuddalore and Vellore. The locations of the colleges included in the sample are indicated in Figure 1.1.

A questionnaire was administered to students at the 16 colleges and the University of Madras between October 2003 and January 2004. Except in the case of three women's colleges (where the college administration preferred to do it), the questionnaire was administered personally by one of the researchers to groups of selected students or to the gathering of all selected students of a specific college with the help of the college authorities. About 130 questionnaires were distributed at each of the centres of higher education selected for our research. Between 40 and 50 students belonging to the three religions among graduate and postgraduate students, giving priority to the former, were selected randomly with the help of college authorities. In cases where there were fewer than 40 students to represent a particular religion students of the other two religions were chosen at random to make up a total of about 130 respondents per college. Of the 2.180 questionnaires thus distributed to college students, 2.012 were returned, of which 1.920 were found to be valid. A list of the participating colleges with exact numbers of respondents appears in appendix A.

The demographic characteristics of our (valid) respondents are as follows. Among our respondents 55.6\% are women and the remaining $44.4 \%$ men. As 


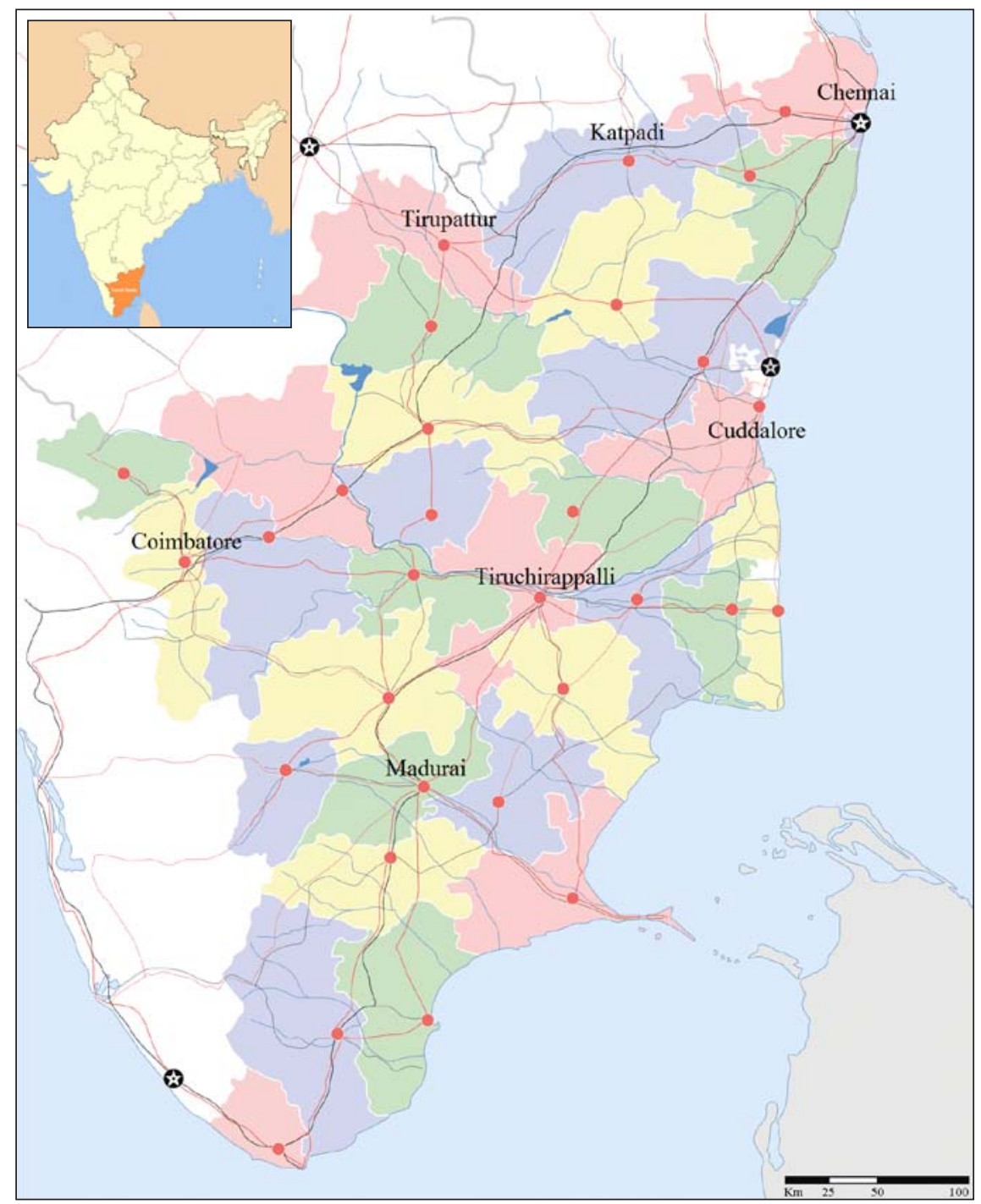

FIGURE 1.1 Map showing the location of colleges in Tamil Nadu included in the sample.

for religious affiliation, $41.1 \%$ are Hindus, $45.3 \%$ are Christians $(28.1 \%$ Catholics, $12.8 \%$ Protestants and $4.4 \%$ from other Christian denominations); $13.3 \%$ are Muslims and a handful (0.4\%) are Jains and Buddhists. As the study focused on Christians, Hindus and Muslims, students belonging to other religions were not included in our analysis. The percentages of students according to religious affiliation do not reflect the ratio in the Tamil Nadu college student population. The relatively higher proportions of Muslims and Christians in our 
sample are necessary to permit statistically meaningful analysis and cross-religious comparison. That there are fewer Muslims than Christians in our sample results from the fact that Muslims rarely attend colleges other than their own, which are also fewer in number. The high number of Christians follows from our need to have sufficient representation of Catholics, Protestants and adherents of other Christian denominations with a view to comparing the Christian groups as part of a further study. Almost all respondents (98.4\%) are in the 17 to 25 age group, which qualifies them as youths. The vast majority (86\%) are undergraduates, $65.6 \%$ of these in the final or third year of their studies. Our study focused on third or final year undergraduates, since not all of them would continue with postgraduate studies. Only $13.7 \%$ of our respondents are postgraduate students and a tiny group $(0.3 \%)$ is engaged in advanced studies (MPhil. and PhD).

\subsection{Design of Analysis}

In this section we first describe the design of analysis of the four research questions regarding the intermediate variables (see chapters $3-6$ ). Next we describe the design of analysis of the research questions regarding our dependent variable (see chapters 7-8).

To answer our first research question concerning the construction of crossreligious comparative models of religious variables we follow two procedures. In the first procedure we assess the dimensionality of the measurement scale via factor analysis. In the second procedure we test whether the scale can be used to compare the ideas, experiences or attitudes of different religious groups by means of a measurement invariance test.

The assessment of comparable dimensionality involves a three step factor analysis. (a) To achieve this we first construct a category for the adherents of all three religions by conducting a factor analysis of the scale for all respondents (Christians, Hindus and Muslims) together. In including all respondents in the same analysis we assume that the models of religiously inspired conflict in these groups have the same structure. The criteria used in the factor analysis are: eigenvalue $>1$; commonality $>.20$; factor loadings $>.30$, and if items load high on two factors, the difference in factor loading should be $>.15$. (b) The second step is to examine the three religious groups separately. These separate analyses should show whether the overall structure of the first step holds good for each group individually. In other words, we want to find out if the models of religiously inspired conflict established in the overall analysis recur in the analyses relating to particular groups in the case of all or of only some items. 
The purpose of this step is to uncover intergroup differences. (c) These differences are eliminated in the third step, where we determine the commensurable concept after checking for structural differences between the models specific to each religious group. Since we can only compare commensurable factors, we have to apply the filter of commonality: what is distinctive is filtered out. The differences (in measurement) between the groups are therefore eliminated in this final step. Only in this last step can we speak of a cross-religious comparative model (i.e. comparable dimensions for all religious groups). In the ensuing chapters we only report the results of the third step of factor analysis (for the sake of simplicity).

In the second procedure we assess the scalar invariance of the factors yielded by the factor analysis. There is a longstanding debate in cross cultural measurement on whether measures can be used in different cultural contexts (e.g. Kumata \& Schram 1956). A formal test of cross cultural comparability, using structural equation modelling, has been suggested by Meredith (1993). This procedure starts with the simplest form of invariance - factorial invariance and ends with the strictest form, scalar invariance. In this procedure one first tests whether the measurement models are the same for all groups; if so, there is factorial invariance. Next one tests for metric invariance, that is whether the factor loadings are the same across groups. If so, it becomes meaningful to compare the relationships of this factor with other factors (that also exhibit metric invariance). The last test is that of scalar invariance. This test implies that factor structure, factor loadings and item intercepts are equal across the groups. If that test holds good, it becomes meaningful to compare the means of the factors (or the composite scores) across the groups. The factor models were all estimated with the ML procedure available in Lisrel 8.8 (Jöreskog \& Sörbom, 1996). The models were evaluated by means of JRule (Saris, Satorra \& Van der Veld 2009), a computer program that uses the output of Lisrel and evaluates whether or not constrained parameters are misspecified, taking into account the power of the MI test. The analytic strategy that we use starts with the least restricted model (see Van der Veld \& Saris 2011). To test for misspecifications we use the same values for delta as one would like to detect with high power tests. In the test for configural invariance we use a delta of 0.25 for cross-loadings and a delta of 0.10 for correlated errors. In the test for metric invariance we use the same deltas, plus a delta of 0.15 for equality constraints on factor loadings. In the test for scalar invariance we use the same deltas, plus a delta of 0.07 for item intercepts. For tests of the equality of factor means we also used a delta of 0.07 . We should point out that it is not absolutely necessary to solve all misspecifications, because one can always expect some misspecifications resulting from chance alone. We can also accept partial scalar invariance (Byrne, 
Shavelson \& Muthén, 1989) in cases where there are at least two invariant indicators per group. This is unproblematic as long as the analysis is continuous in the framework of SEM. There are no rules or measures to decide what constitutes a serious deviation. However, we accept deviations as harmless for our conclusions when they are only slightly larger than the misspecifications.

The second research question aims at differences in agreement with religious variables, here religious convictions and attitudes. In our analysis we calculate the group mean and standard deviation for the three groups of students (Christians, Muslims and Hindus). We check whether cross-religious differences are significant by means of a Scheffé test or, in the case of comparison between the means of two groups, by means of a T-test (chapter 6).

The third research question is answered by means of associations (rho) between the personal characteristics of students (socio-cultural, socio-economic and socio-religious) and religious attitudes/ideas. For nominal variables with two answer categories (here the variables gender, language and field of specialization), we present the means of each religious group on a variable in order to interpret the direction of the correlation. We mention all significant associations, but focus on those which are relevant enough to cite in theory formation, in our case associations that are moderately strong $(.15<\mathrm{r}<.30)$ or strong $(\mathrm{r} \geq .30)$.

The fourth question is answered by means of a linear regression analysis (method: Enter) in which we define the aforementioned student characteristics as independent variables and the issues discussed in the separate chapters as dependent variables. In other words, we explain differences in the dependent variable in terms of the variety of some student characteristics. We discuss only those variables that yielded relevant $(\mathrm{r} \geq .20)$ and significant $(\mathrm{p} .<.000)$ correlations with the dependent variable concerned in at least one of the religious groups. We do not demand this level of association for each group, because we expect different predictors in distinct religious groups. However, to guarantee comparison of the analyses we include the student characteristic in the regression analysis of each group of respondents (Christians, Muslims, Hindus) as soon as it proves to be relevant for one of these groups. The regression analysis results in an explained variance (coefficient of determination $\mathrm{R}^{2}$ ) in which the independent variables assume certain significant weightings, expressed by the standardized regression coefficient $\beta$. The standardized regression coefficient $(\beta)$ expresses the relative weight of the variable concerned in the total explained variance. Since we inserted personal characteristics that yielded relevant and significant correlations with positive in-group attitudes in any of the religious groups, it is not surprising that some independent variables are neither significant nor relevant for certain religious groups. However, 
to guarantee comparison we did include the same dependent variables in the regression analysis for all religious groups.

The design of analysis of the research questions regarding our dependent variable (see chapters $7-8$ ) is largely the same as that for religious attitudes/ ideas. Only the fourth question has a different analytic design. To analyse the predictors of the causes of religious conflicts we used Structural Equation Modelling (SEM technique) (cf. Kline 2005). We want to know which variables predict the level of agreement with the causes of religious conflicts. Or, to put it differently, what ideas in the minds of religious people predict their interpretation of the causes of religious conflicts? Our research is comparative. We not only want to know which predictors can be found in each group of students (Christian, Muslim and Hindu), but also want to test whether predictors are the same for all groups. Do Christians, Muslims and Hindus agree on the influence of interreligious variables on causes of religious conflicts? With the help of Structural Equation Modelling (SEM) we can test whether predictors are significantly different for Christian, Muslim and Hindu students. We applied a model generating analyses of the data using the Amos program. Structural Equation Modelling presupposes well developed theoretical expectations about the relation between the variables. Our model refers to the influence of beliefs on causes of force-driven religious conflict. The model specifies our hypotheses with regard to the direct influence of beliefs on religious conflicts. Two types of descriptive beliefs in the religious meaning system are included in the model: religiocentrism and models of interpreting religious plurality. For religiocentrism two variables are included: a positive in-group attitude (i.e. towards one's own religion) and negative out-group attitudes (i.e. towards others' religions). For the respondent's convictions about religious plurality three variables are included: monism, commonality pluralism and differential pluralism. Two prescriptive beliefs are included in the model: experience of mystical union with an ultimate reality and participation in institutional religious practices. The descriptive and prescriptive beliefs are so-called 'endogenous variables', because they belong to the core of the causal model and their value is determined by the state of other values in the system. The student's characteristics are so-called 'exogenous variables' ( $\mathrm{x}$-variables) because their value is determined outside the model in which it is used. The following personal characteristics are included: socio-cultural background, socio-economic background and socio-religious background. In our model these background characteristics can influence religious beliefs (cf. Durkheim 1915). In the category of socio-cultural variables we included age, gender, mother tongue, caste, urbanization and field of educational specialization. As socio-economic variables the following were included in our analysis: mother's occupation, father's 
occupation, mother's education, father's education. In the category of socioreligious variables we included years attending religious schools (of one's own religion) and socializing agents in the religious domain (parents, relatives, friends, religious community, teachers/professors and media). 